\title{
Performance of blueberry cultivars under mild winter conditions
}

\author{
José Gilberto Sousa Medeiros ${ }^{1}$ Claudine Maria De Bona ${ }^{2}$ \\ Francine Lorena Cuquel ${ }^{3}$ Luiz Antonio Biasi ${ }^{3 *}$
}

${ }^{1}$ Instituto Federal do Pará (IFPA), Campus Castanhal, Castanhal, PA, Brasil.

${ }^{2}$ Instituto Agronômico do Paraná (IAPAR), Curitiba, PR, Brasil.

${ }^{3}$ Departamento de Fitotecnia e Fitossanitarismo, Universidade Federal do Paraná (UFPR), Rua dos Funcionários, 1540, 80035-050, Curitiba, PR, Brasil. E-mail: biasi@ufpr.br. "Corresponding author.

\begin{abstract}
Evaluation of yield performance is important to find the most adapted blueberry cultivars in a particular region. This research aimed to evaluate the flowering and hasvesting periods, the production per plant, and fruit quality of eight rabbiteye blueberry cultivars (Aliceblue, Bluebelle, Bluegem, Briteblue, Climax, Delite, Powderblue, and Woodard) and two highbush blueberries (Georgiagem and O'Neal), in mild winter conditions in Pinhais-PR. Flowering and harvesting periods, production, berry weight, size, $p H$, soluble solids, titratable acidity, ratio and color of the fruits were evaluated in the 2013/2014 and 2014/2015 growing seasons, when the plants had two and three years old, respectively. Cultivars flowered from August to September, and harvest was concentrated in November and December. Berry weight, size, pH, soluble solids and acidity varied among the cultivars. The average ratios of 14.97 and 13.39 for each crop proved that the cultivars have good fruit quality. There was little variation in fruit color in the two years evaluated. Blueberry cultivars showed the staining characteristics and physical and chemical attributes of quality compatible to blueberry from other traditional regions. Under mild winter conditions, young plants of rabbiteye blueberry cultivars, Climax, Delite, Bluegem and Powderblue, are the most productive, while the highbusch cultivars bear few fruits.
\end{abstract}

Key words: Vaccinium spp, small fruits, chilling hours, postharvest.

Desempenho de cultivares de mirtileiro em condição de inverno ameno

RESUMO: A avaliação do desempenho produtivo é importante para encontrar as cultivares de mirtileiro mais adaptadas à uma determinada região. Este trabalho teve como objetivo avaliar o periodo de floração e de colheita, a produção por planta e a qualidade de frutos de oito cultivares de mirtileiro do grupo rabbiteye (Aliceblue, Bluebelle, Bluegem, Briteblue, Climax, Delite, Powderblue e Woodard) e duas do grupo highbush (Georgiagem e O'Neal) em condição de inverno ameno em Pinhais-PR. Foram avaliadas as datas de início e final de floração, início e final de colheita, produção por planta, massa, tamanho de fruto, $\mathrm{pH}$, teor de sólidos solúveis, acidez titulável, ratio e coloração nos ciclos produtivos de 2013/2014 e 2014/2015, quando as plantas possuiam dois e três anos, respectivamente.As cultivares estudadas apresentaram floração nos meses de agosto e setembro, concentrando a colheita nos meses de novembro e dezembro. Houve diferenças entre as cultivares quanto a massa do fruto, tamanho, pH, teor de sólidos solúveis e a acidez. O ratio médio de 14,97 e 13,39 obtido em cada safra provou que as cultivares tem boa qualidade de frutos. A coloração dos frutos apresentou poucas variações nos dois anos avaliados. O mirtilo das cultivares avaliadas apresentou características de coloração e atributos fisicos e químicos de qualidade compativel com o mirtilo de outras regiões tradicionalmente produtoras. Em região com inverno ameno, plantas jovens das cultivares Climax, Delite, Bluegem e Powderblue, do grupo rabbiteye, são as mais produtivas, enquanto as cultivares do grupo highbush produzem poucos frutos.

Palavras-chave: Vaccinium spp, pequenas frutas, horas de frio, pós-colheita.

\section{INTRODUCTION}

Blueberry (Vaccinium spp) is a fruit species from Europe and North America, where it is very appreciated for its exotic flavor and functional properties (CANTUARIAS-AVILÉS et al., 2014). Worldwide interest in the blueberry cultivation is due to its high profitability and high antioxidant capacity, since it presents phenolic compounds such as anthocyanins, flavonoids and cinnamic acid derivatives (CARDEÑOSA et al., 2016), responsible for fighting free radicals and reducing bad cholesterol (RETAMALES et al., 2014; ENGLAND, 2015; KANG et al., 2015). LI et al. (2016) reported 13 different types of anthocyanins in blueberrie cultivars grown in China, being 
malvidin (41.0\%), delphinidin (33.1\%), and petunidin $(17.3 \%)$ the major ones.

Blueberries were introduced in Brazil around 1980, and are mostly cultivated in Rio Grande do Sul and Santa Catarina States, but also in Paraná, São Paulo and Minas Gerais. Most cultivars grown in Brazil belong to the rabbiteye group, which require less cold than highbush blueberries, but do not produce properly in regions with less than 200 chill hours (CANTUARIAS-AVILÉS et al., 2014).

All blueberry cultivars grown in Brazil were introduced and require adaptation studies for different regions. The primary focus of blueberry breeding programs around the world has been the development of lower chill requirement cultivars (LOBOS \& HANCOCK, 2015). Dormancy breakers may be an alternative in milder climates (PICOLOTTO et al., 2014).

Observing the performance of cultivars in the region of interest is the most efficient way to select the best adapted genotypes for cultivation. The purpose of this study was to evaluate tflowering and harvest periods, production and fruit quality of highbush and rabbiteye blueberry cultivars in mild winter conditions.

\section{MATERIALS AND METHODS}

The study was conducted in two growing seasons, 2013/2014 and 2014/2015, when the plants had two and three years old after planting, in a blueberry collection located in Pinhais-PR, Brazil, latitude $25^{\circ} 25^{\prime} \mathrm{S}$, longitude $49^{\circ} 08^{\prime} \mathrm{W}$ and altitude of 930 meters. The climate, according to Köppen climate classification, is the maritime temperate climate $(\mathrm{Cfb})$.

Soil analyses presented the following characteristics: $\mathrm{pH} \mathrm{CaCl}=5.0 ; \mathrm{Al}^{+3}=0.0 \mathrm{cmol}_{\mathrm{c}} \mathrm{dm}^{-3}$; $\mathrm{H}^{+}+\mathrm{Al}^{+3}=7.2 \mathrm{cmol}_{\mathrm{c}} \mathrm{dm}^{-3} ; \mathrm{Ca}^{+2}=7.1 \mathrm{cmol}_{\mathrm{c}} \mathrm{dm}^{-3} ; \mathrm{Mg}^{+2}=$ $3.2 \mathrm{cmol}_{\mathrm{c}} \mathrm{dm}^{-3} ; \mathrm{K}^{+}=0.48 \mathrm{cmol}_{\mathrm{c}} \mathrm{dm}^{-3} ; \mathrm{P}=15.6 \mathrm{mg} \mathrm{dm}^{-3}$; $\mathrm{C}=19.2 \mathrm{~g} \mathrm{dm}^{-3}$; base saturation $=60 \%$ and clay content of $500 \mathrm{~g} \mathrm{~kg}^{-1}$. Before planting, the soil was acidified by sulfur incorporation of $204 \mathrm{~kg} \mathrm{ha}^{-1}$.

Collection consisted of 8 rabbiteye cultivars (Aliceblue, Bluebelle, Bluegem, Briteblue, Climax, Delite, Powderblue and Woodard) and 2 highbush cultivars (Georgiagem and O'Neal) arranged in a randomized block design with four replicates and ten plants per plot. The orchard was established in September 2011, with spacing of $0.7 \times 3.5 \mathrm{~m}$, in ridge, with mulch and drip irrigation system.

Flowering and harvest periods were performed according to bud development stages, or else, early flowering stage (more than $5 \%$ opened blossoms), end of flowering ( $90 \%$ opened blossoms), beginning and end of harvest.

Fruits were harvested at full maturity stage (SAFTNER et al., 2008) in each treatment for the evaluations of: average production per plant $\left(\mathrm{g} \mathrm{plant}^{-1}\right)$, fresh berry weight $(\mathrm{g})$; berry size $(\mathrm{mm})$, hydrogen potential $(\mathrm{pH})$, soluble solids content (SS), titratable acidity and epidermal color. SS was analysed by hand held refractometer. TA was determided by neutralization titration of a known volume of blueberry juice with $0.1 \mathrm{~N} \mathrm{NaOH}$ until $\mathrm{pH}$ reached 8.2, and expressed as citric acid percentage. Berry size was meansured in the equatorial diameter by digital caliper rule.

The ratio was obtained by the relationship between the total soluble solids and titratable acidity. Fruits were homogenized within each treatment and selected according to appearance (absence of injuries and defects). Samples were then divided into four replicates of 36 fruits.

Fruit epiderm color was determined by portable colorimeter, using the CIE $\mathrm{L}^{*} \mathrm{a}^{*} \mathrm{~b}^{*}$ scale, with direct reading of $\mathrm{L}^{*}$ (luminosity) values, $\mathrm{a}^{*}$ (red contribution for positive values and green contribution for negative values) and $b^{*}$ (yellow contribution for positive values and blue contribution for negative values). The hue angle $\left(\mathrm{h}^{*}\right)$ and color saturation, chroma $\left(C^{*}\right)$ were calculated from $a^{*}$ and $b^{*}$, values, according to the equations: $h^{*}=\operatorname{arctang}\left(b^{*} / a^{*}\right)$ and $C^{*}=\left[\left(a^{*}\right)+\left(b^{*}\right)\right]^{1 / 2}$.

The experimental design was a randomized complete blocks, with a factorial treatment arrangement ( 2 years x 10 cultivars), with four replicates, ten plants per plot and four useful plants. Data were submitted to analysis of variance and averages compared by the Tukey test.

\section{RESULTS}

Flowering period was similar in both cycles, $2013 / 2014$ and 2014/2015, ranging from 28 to 35 days, starting earlier in the second cycle. Conversely the harvest period showed a large variation between cultivars in the cycle 2013/2014, and was more stable in the next cycle, ranging from 21 days for 'Aliceblue', 'Georgiagem' and 'O'Neal' to 35 days for 'Delite', 'Powderblue' and 'Woodard' (Table 1).

In the 2014/2015 cycle, flowering occurred earlier than in the previous year for all cultivars, with an average anticipation of two weeks. This fact may be associated mostly to higher temperatures in periods prior to flowering rather than the cold hours accumulated, since that in the second cycle temperatures were higher than the previous year, being observed 
Table 1 - Flowering and harvest period of ten blueberry cultivars in two cycles (2013/2014 and 2014/2015), in Pinhais, PR, Brazil ${ }^{(1)}$.

\begin{tabular}{|c|c|c|c|c|c|c|}
\hline \multirow{2}{*}{ Cultivar } & \multicolumn{3}{|c|}{--------------------------------Flowering--------------------------- } & \multicolumn{3}{|c|}{------------------------------Harvest--------------------------- } \\
\hline & Beginning & End & Flowering time (days) & Beginning & End & Harvest time (days) \\
\hline ------------. & $\cdots$ & - & ---------2013/2014----- & 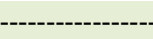 & -------- & ----------------------- \\
\hline Aliceblue & $26 / 08$ & $23 / 09$ & $28^{\text {ns }}$ & - & - & - \\
\hline Bluebelle & $12 / 08$ & $16 / 09$ & 35 & $09 / 12$ & $16 / 12$ & $08 \mathrm{c}$ \\
\hline Bluegem & $12 / 08$ & $16 / 09$ & 35 & $02 / 12$ & $23 / 12$ & $22 \mathrm{ab}$ \\
\hline Briteblue & $19 / 08$ & $23 / 09$ & 35 & $16 / 12$ & $23 / 12$ & $08 \mathrm{c}$ \\
\hline Clímax & $19 / 08$ & $23 / 09$ & 35 & $25 / 11$ & $23 / 12$ & $29 a$ \\
\hline Delite & $26 / 08$ & $23 / 09$ & 28 & $09 / 12$ & $23 / 12$ & $15 \mathrm{bc}$ \\
\hline Georgiagem & $26 / 08$ & $30 / 09$ & 35 & - & - & - \\
\hline O’Neal & $12 / 08$ & $09 / 09$ & 28 & - & - & - \\
\hline Powderblue & $19 / 08$ & $23 / 09$ & 35 & $02 / 12$ & $23 / 12$ & $22 \mathrm{ab}$ \\
\hline Woodard & $19 / 08$ & $23 / 09$ & 35 & $09 / 12$ & $16 / 12$ & $08 \mathrm{c}$ \\
\hline CV (\%) & & & 18.22 & & & 24.02 \\
\hline 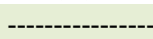 & - & . & 2014/2015----- & 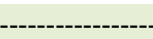 & ------ & ------------------------ \\
\hline Aliceblue & $04 / 08$ & $01 / 09$ & $28^{\mathrm{ns}}$ & $03 / 11$ & $01 / 12$ & $21 b$ \\
\hline Bluebelle & $28 / 07$ & $25 / 08$ & 28 & $03 / 11$ & $01 / 12$ & $28 \mathrm{ab}$ \\
\hline Bluegem & $04 / 08$ & 08/09 & 35 & $03 / 11$ & $01 / 12$ & $28 \mathrm{ab}$ \\
\hline Briteblue & 04/08 & 08/09 & 35 & $03 / 11$ & $01 / 12$ & $28 \mathrm{ab}$ \\
\hline Clímax & 04/08 & 08/09 & 35 & 03/11 & $01 / 12$ & $28 \mathrm{ab}$ \\
\hline Delite & $25 / 08$ & $29 / 09$ & 35 & $03 / 11$ & $08 / 12$ & $35 \mathrm{a}$ \\
\hline Georgiagem & 04/08 & 01/09 & 28 & $03 / 11$ & $24 / 11$ & $21 b$ \\
\hline O’Neal & $28 / 07$ & $25 / 08$ & 28 & $03 / 11$ & $24 / 11$ & $21 b$ \\
\hline Powderblue & $21 / 07$ & $25 / 08$ & 35 & $03 / 11$ & $08 / 12$ & $35 a$ \\
\hline Woodard & $18 / 07$ & $18 / 08$ & 28 & $03 / 11$ & $08 / 12$ & $35 \mathrm{a}$ \\
\hline CV (\%) & & & 17.21 & & & 19.36 \\
\hline
\end{tabular}

${ }^{(1)}$ Means followed by the same lower case letters in the columns do not differ by the Tukey test $(P \leq 0.05)$; ns $=$ no significant.

an increase of $0.51^{\circ} \mathrm{C}$ and $0.80^{\circ} \mathrm{C}$ on the average temperature in July and August, respectively. Whereas, accumulated chilling hours were higher in the first cycle (Table 2). Production was low in the first cycle, when the plants had two years old, and the cultivars didn't differ presenting in average $27.86 \mathrm{~g}$ of fruits per plant. Next year, when the plants had three years old, the difference between cultivars was quite remarkable, especially 'Climax' which was the most productive, reaching over $1 \mathrm{~kg}$ of fruits per plant, followed by 'Delite', 'Bluegem', and 'Powderblue'. 'Aliceblue', 'Georgiagem' and 'O'Neal' did not produce with two years old and were less productive with three years old, togheter 'Briteblue' and 'Woodard' (Table 3).

'Bluebelle' showed the highest berry weight with two years old (1.92g). Next cycle, 'Delite'(1.96g) was superior the others, but didn't differ to 'Bluebelle' $(1.89 \mathrm{~g})$, 'Powderblue' (1.73g) and 'Aliceblue' (1.68g) (Table 3). 'Woodard', 'Bluebelle', and 'Briteblue' produced greater fruits in the first cycle. Fruits were bigger than $15 \mathrm{~mm}$. In the second cycle'Woodard' stood out (Table 3).
Chemical characteristics varied among cultivars. The $\mathrm{pH}$ values were higher in the first cycle compared to the second cycle for all cultivars. There wasn't difference among the cultivars in the 2013/2014 cycle. However, in the second cycle 'Powderblue' showed the highest pH (Table 3). Regarding to soluble solids content, 'Climax' (12.27 ${ }^{\circ}$ Brix) presented significantly higher contents than the other cultivars in the first cycle. In the second cycle 'Powderblue' (13.27 'Brix), and 'Delite' (12.92 ${ }^{\circ}$ Brix) stood out. The more acidic fruits were from Woodard cultivar in both years, reaching 1.00 and $1.88 \%$. The ratio (SS/TA) was higher in Climax (20.57) and Powderblue (18.50) cultivars in the first cycle and higher on Powderblue (19.56) and Delite (19.45) in the second cycle (Table 3 ).

There was little variation in luminosity $\left(\mathrm{L}^{*}\right)$ among the cultivars, which presented averages from 29.00 to 34.87 in the first and from 27.07 to 35.38 in the second cycle. 'Powderblue' was superior the others in both cycles (Table 4). The parameter 
Table 2 - Yield, berry weight, berry size, $\mathrm{pH}$, soluble solids content (SS), titratable acidity (TA) and ratio (SS/TA) of blueberry cultivars, in two cycles (2013/2014 and 2014/2015), in Pinhais, PR, Brazil ${ }^{(1)}$.

\begin{tabular}{|c|c|c|c|c|c|c|c|c|}
\hline \multirow[b]{2}{*}{ Cultivar } & \multicolumn{3}{|c|}{------------------Yield $\left(\mathrm{g} \mathrm{pl}^{-1}\right.$ )---------------- } & \multicolumn{2}{|c|}{-------Berry weight (g)-------- } & \multicolumn{3}{|c|}{-------------Berry size (mm)-------------- } \\
\hline & \multicolumn{2}{|c|}{$2013 / 14$} & $2014 / 15$ & $2013 / 14$ & 201 & \multicolumn{2}{|c|}{$2013 / 14$} & $2014 / 15$ \\
\hline Aliceblue & \multicolumn{2}{|c|}{--} & $27.12 \mathrm{e}$ & -- & $1.68 \mathrm{abc}$ & \multicolumn{2}{|c|}{--} & $12.48 \mathrm{~d}$ \\
\hline Bluebelle & \multicolumn{2}{|c|}{$30.60 \mathrm{aB}$} & $219.17 \mathrm{dA}$ & $1.92 \mathrm{aA}$ & $1.89 \mathrm{abA}$ & \multicolumn{2}{|c|}{$15.37 \mathrm{abA}$} & $13.30 \mathrm{cdB}$ \\
\hline Bluegem & \multicolumn{2}{|c|}{$25.50 \mathrm{aB}$} & $586.80 \mathrm{bcA}$ & $1.52 \mathrm{bA}$ & $1.42 \mathrm{cA}$ & \multicolumn{2}{|c|}{$13.67 \mathrm{dA}$} & $13.69 \mathrm{bcA}$ \\
\hline Briteblue & \multicolumn{2}{|c|}{$21.18 \mathrm{aA}$} & $96.62 \mathrm{deA}$ & $1.67 \mathrm{abA}$ & $1.64 \mathrm{bcA}$ & \multicolumn{2}{|c|}{$15.24 \mathrm{abcA}$} & $13.54 \mathrm{cdB}$ \\
\hline Clímax & \multicolumn{2}{|c|}{$26.78 \mathrm{aB}$} & $1057.25 \mathrm{aA}$ & $1.71 \mathrm{abA}$ & $1.61 \mathrm{bcA}$ & \multicolumn{2}{|c|}{$14.53 \mathrm{bcdA}$} & 14.69abA \\
\hline Delite & \multicolumn{2}{|c|}{$26.36 \mathrm{aB}$} & $675.24 \mathrm{bA}$ & $1.65 \mathrm{abB}$ & $1.96 \mathrm{aA}$ & \multicolumn{2}{|c|}{$14.21 \mathrm{cdA}$} & $13.82 \mathrm{bcA}$ \\
\hline Georgiagem & \multicolumn{2}{|c|}{--} & $50.97 \mathrm{e}$ & -- & $1.57 \mathrm{c}$ & \multicolumn{2}{|c|}{--} & $13.36 \mathrm{~b}$ \\
\hline O’Neal & \multicolumn{2}{|c|}{--} & $50.55 \mathrm{e}$ & -- & $1.47 \mathrm{c}$ & \multicolumn{2}{|c|}{--} & $12.97 \mathrm{c}$ \\
\hline Powderblue & \multicolumn{2}{|c|}{$31.65 \mathrm{aB}$} & $478.70 \mathrm{cA}$ & $1.71 \mathrm{abA}$ & $1.73 \mathrm{abcA}$ & 14.4 & $\operatorname{cd} A$ & $13.88 \mathrm{abcA}$ \\
\hline Woodard & & & $94.83 \mathrm{deA}$ & $1.76 \mathrm{abA}$ & & 16. & $\mathrm{taA}$ & $15.03 \mathrm{aB}$ \\
\hline CV (\%) & & 41.1 & & & 8.35 & & 4.06 & \\
\hline & ------------ & H-------------- & -----------SS & ix)----------- & ------TA ( & ric acid)----- & --------Ratic & (SS/TA)-------- \\
\hline Cultivar & $2013 / 14$ & $2014 / 15$ & $2013 / 14$ & $2014 / 15$ & $2013 / 14$ & $2014 / 15$ & $2013 / 14$ & $2014 / 15$ \\
\hline Aliceblue & -- & $2.84 \mathrm{ab}$ & -- & $10.60 \mathrm{~cd}$ & -- & $0.74 d$ & -- & $14.32 \mathrm{bcd}$ \\
\hline Bluebelle & $3.24 \mathrm{aA}$ & $2.48 \mathrm{~dB}$ & $10.20 \mathrm{cA}$ & $10.37 \mathrm{cdA}$ & $0.80 \mathrm{abB}$ & $1.22 \mathrm{bA}$ & $12.72 \mathrm{cA}$ & $8.91 \mathrm{efB}$ \\
\hline Bluegem & $3.13 \mathrm{aA}$ & $2.83 \mathrm{abB}$ & $10.90 \mathrm{bcA}$ & $10.82 \mathrm{cdA}$ & $0.74 \mathrm{abB}$ & $1.03 \mathrm{bcA}$ & $14.67 \mathrm{bcA}$ & $10.51 \mathrm{defB}$ \\
\hline Briteblue & $3.13 \mathrm{aA}$ & $2.85 \mathrm{abB}$ & $10.72 b c A$ & $11.47 \mathrm{bcA}$ & $0.75 \mathrm{abB}$ & $0.70 \mathrm{dA}$ & $14.13 \mathrm{bcA}$ & 16.26abcA \\
\hline Clímax & $3.14 \mathrm{aA}$ & $2.68 \mathrm{bcdB}$ & $12.27 \mathrm{aA}$ & $11.37 \mathrm{cB}$ & $0.60 \mathrm{bB}$ & $1.28 \mathrm{bA}$ & $20.57 \mathrm{aA}$ & $8.89 \mathrm{efB}$ \\
\hline Delite & $3.08 \mathrm{aA}$ & $2.87 \mathrm{abB}$ & $10.97 \mathrm{bcB}$ & $12.92 \mathrm{aA}$ & $0.84 \mathrm{abA}$ & $0.67 \mathrm{~dB}$ & $13.13 \mathrm{bcB}$ & $19.45 \mathrm{aA}$ \\
\hline Georgiagem & -- & $2.82 \mathrm{ab}$ & -- & $12.67 \mathrm{ab}$ & -- & $0.70 \mathrm{~d}$ & -- & $17.94 \mathrm{ab}$ \\
\hline O’Neal & -- & $2.79 \mathrm{abc}$ & -- & $10.10 \mathrm{~d}$ & -- & $0.85 \mathrm{~cd}$ & -- & $11.84 \mathrm{cde}$ \\
\hline Powderblue & $3.12 \mathrm{aA}$ & $2.94 \mathrm{aB}$ & $11.82 \mathrm{abB}$ & $13.27 \mathrm{aA}$ & $0.65 \mathrm{bA}$ & $0.70 \mathrm{dA}$ & $18.50 \mathrm{abA}$ & $19.56 \mathrm{aA}$ \\
\hline Woodard & $3.20 \mathrm{aA}$ & $2.59 \mathrm{cdB}$ & $11.05 \mathrm{abcA}$ & $11.40 \mathrm{cA}$ & $1.00 \mathrm{aB}$ & $1.88 \mathrm{aA}$ & $11.05 \mathrm{cA}$ & $6.17 \mathrm{fB}$ \\
\hline CV (\%) & & & & & & & & 6.16 \\
\hline
\end{tabular}

${ }^{(1)}$ Means followed by the same lower case letters in the columns and capital letters in the lines do not differ by the Tukey test $(p P \leq 0.05)$.

$\mathrm{a}^{*}$ varied among cultivars in both cycles, but it was always positive and in general higher in the first cycle than the second. Parameter $b^{*}$ also varied among cultivars and it was always negative. In the first cycle, this parameter was more negative for all cultivars. Parameter $\mathrm{a}^{*}$, which quantifies the green color variation $\left(\mathrm{a}^{*}<0\right)$ to red $\left(\mathrm{a}^{*}>0\right)$, for presenting positive values indicated that the fruits have a higher intensity of red color; although, as the values were low and $b^{*}$ values were negative, blue color prevailed. There wasn't difference to tonality $\left(\mathrm{h}^{*}\right)$ among cultivars in the first cycle, but in the second cycle 'Georgiagem' was superior the others and didn't differ to 'Powderblue', 'Bluegem', and 'Aliceblue'. There was variation among saturation $\left(C^{*}\right)$ values of the cultivars, with a pronounced reduction in the cycle $2014 / 2015$ in relation to $2013 / 2014$ for all cultivars (Table 4).

\section{DISCUSSION}

There was little variation of blooming period among the cultivars in both cycles, similarly to results presented by ANTUNES et al. (2008) in the region of Pelotas-RS. However, in the second cycle, the flowering occurred earlier than the first cycle for all cultivars. Because of this difference in the beginning and end of flowering, harvest periods were displaced during the years, with a concentration in November in the 2013/2014 cycle, and December in the $2014 / 2015$ cycle. This is a favorable period for blueberries commercialization in the domestic market, since harvest occurs during the Christmas season, and there is a great demand for blueberries.

The poorer production observed during the first cycle was because the plants were still young, with two years old. In the second cycle there was 
Table 3 - Color parameters $\left(\mathrm{L}^{*}, \mathrm{a}^{*}, \mathrm{~b}^{*}\right)$, tonality (hue) e saturation of blueberry cultivars, in two cycles (2013/2014 and 2014/2015) in Pinhais, PR, Brazil ${ }^{(1)}$.

\begin{tabular}{|c|c|c|c|c|c|c|}
\hline \multirow{3}{*}{ Cultivar } & \multicolumn{6}{|c|}{ 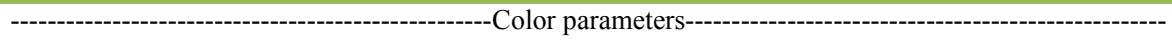 } \\
\hline & \multicolumn{2}{|c|}{-------------------L'------------------ } & \multicolumn{2}{|c|}{-----------------a*'------------------ } & \multicolumn{2}{|c|}{-----------------b"------------------ } \\
\hline & $2013 / 14$ & $2014 / 15$ & $2013 / 14$ & $2014 / 15$ & $2013 / 14$ & $2014 / 15$ \\
\hline Aliceblue & -- & $31.22 \mathrm{bc}$ & -- & $1.10 \mathrm{bc}$ & -- & $-2.66 \mathrm{bcd}$ \\
\hline Bluebelle & $28.00 \mathrm{dA}$ & $27.07 \mathrm{eA}$ & $4.23 \mathrm{aA}$ & $4.11 \mathrm{aA}$ & $-5.33 \mathrm{dA}$ & $-2.06 \mathrm{cdB}$ \\
\hline Bluegem & $33.18 \mathrm{abA}$ & $30.55 \mathrm{bcB}$ & $3.83 \mathrm{abA}$ & $1.27 \mathrm{bcB}$ & $-7.23 \mathrm{abcA}$ & $-3.82 \mathrm{abB}$ \\
\hline Briteblue & $28.75 \mathrm{cdA}$ & $29.91 \mathrm{cdA}$ & 3.71abA & $2.45 \mathrm{bB}$ & $-5.67 \mathrm{dA}$ & $-2.08 \mathrm{cdB}$ \\
\hline Clímax & $29.26 \mathrm{cdA}$ & $29.71 \mathrm{cde} A$ & $2.86 \mathrm{abA}$ & $2.18 \mathrm{bA}$ & $-6.54 \mathrm{bcbA}$ & $-3.84 \mathrm{abB}$ \\
\hline Delite & $31.54 \mathrm{bcA}$ & $33.01 \mathrm{abA}$ & 4.11abA & $2.68 \mathrm{abB}$ & $-6.23 \mathrm{cdA}$ & $-3.18 b c B$ \\
\hline Georgiagem & -- & $29.36 \mathrm{cde}$ & -- & $0.30 \mathrm{c}$ & -- & $-2.55 \mathrm{~cd}$ \\
\hline O’Neal & -- & $27.15 \mathrm{de}$ & -- & $1.48 \mathrm{bc}$ & -- & $-1.55 \mathrm{~d}$ \\
\hline Powderblue & $34.87 \mathrm{aA}$ & $35.38 \mathrm{aA}$ & $3.45 \mathrm{abA}$ & $1.42 \mathrm{bcB}$ & $-8.31 \mathrm{aA}$ & $-4.47 \mathrm{aB}$ \\
\hline Woodard & $29.53 \mathrm{cdA}$ & $28.53 \mathrm{cde} A$ & $2.61 \mathrm{bA}$ & $1.74 \mathrm{bcA}$ & $-7.70 \mathrm{abA}$ & $-3.23 \mathrm{abcB}$ \\
\hline \multirow[t]{3}{*}{$\mathrm{CV}(\%)$} & \multicolumn{2}{|c|}{4.63} & \multicolumn{2}{|c|}{29.65} & \multicolumn{2}{|c|}{13.65} \\
\hline & \multicolumn{3}{|c|}{-----------------Tonality Hue (rad)------------------ } & \multicolumn{3}{|c|}{------------------Saturation (Chroma)------------------- } \\
\hline & $2013 / 14$ & \multicolumn{2}{|c|}{$2014 / 15$} & 2013/14 & \multicolumn{2}{|c|}{$2014 / 15$} \\
\hline Aliceblue & -- & \multicolumn{2}{|c|}{$-1.15 \mathrm{abc}$} & -- & \multicolumn{2}{|c|}{$2.98 \mathrm{cde}$} \\
\hline Bluebelle & $-0.91 \mathrm{aA}$ & \multicolumn{2}{|c|}{$-0.50 \mathrm{eB}$} & $6.89 \mathrm{cdA}$ & \multicolumn{2}{|c|}{$4.69 \mathrm{aB}$} \\
\hline Bluegem & $-1.07 \mathrm{aA}$ & \multicolumn{2}{|c|}{$-1.24 \mathrm{abA}$} & $8.21 \mathrm{abA}$ & \multicolumn{2}{|c|}{$4.04 \mathrm{abcB}$} \\
\hline Briteblue & $-0.99 \mathrm{aA}$ & \multicolumn{2}{|c|}{$-0.73 \mathrm{deB}$} & $6.84 \mathrm{dA}$ & \multicolumn{2}{|c|}{$3.30 \mathrm{bcdeB}$} \\
\hline Clímax & $-1.15 \mathrm{aA}$ & \multicolumn{2}{|c|}{$-1.05 \mathrm{bcdA}$} & $7.15 \mathrm{cdA}$ & \multicolumn{2}{|c|}{$4.45 \mathrm{abB}$} \\
\hline Delite & $-0.98 \mathrm{aA}$ & \multicolumn{2}{|c|}{$-0.88 \mathrm{cdA}$} & $7.84 \mathrm{cdA}$ & \multicolumn{2}{|c|}{$4.32 \mathrm{abB}$} \\
\hline Georgiagem & -- & \multicolumn{2}{|c|}{$-1.44 \mathrm{a}$} & -- & \multicolumn{2}{|c|}{$2.57 \mathrm{de}$} \\
\hline O’Neal & -- & \multicolumn{2}{|c|}{$-0.81 \mathrm{cde}$} & -- & \multicolumn{2}{|c|}{$2.15 \mathrm{e}$} \\
\hline Powderblue & $-1.17 \mathrm{aA}$ & \multicolumn{2}{|c|}{$-1.27 \mathrm{abA}$} & $9.00 \mathrm{aA}$ & \multicolumn{2}{|c|}{$4.71 \mathrm{aB}$} \\
\hline Woodard & $-1.24 \mathrm{aA}$ & \multicolumn{2}{|c|}{$-1.08 b c d A$} & $8.13 \mathrm{abcA}$ & & abcdB \\
\hline $\mathrm{CV}(\%)$ & & 14.78 & & & 11.65 & \\
\hline
\end{tabular}

${ }^{(1)}$ Means followed by the same lower case letters in the columns and capital letters in the lines do not differ by the Tukey test $(P \leq 0.05)$.

significant production, with clear differences among cultivars. The highbushs 'Georgiagem' and 'O'Neal' did not produce in the 2013/2014 cycle and produced just a few fruits in the 2014/2015 cycle. This response may be due to lack of climatic adaptation, since these cultivars are more demanding in chill than those belonging to the rabbiteye group. In the Biobío region, Chile, where the highbush cultivars are cultivated, in $37^{\circ} 26^{\prime} \mathrm{S}$, there are around 1237 chilling hours (MUÑOZ-VEGA et al., 2016). In this climatic condition, 'O'Neal' can produce $69 \mathrm{~g}$ per plant in the first year after planting (RETAMAL-SALGADO et al., 2015). Number of accumulated chilling hours in Pinhais-PR is low. During this experiment were observed 174 hours of chill below $7.2^{\circ} \mathrm{C}$ until August $12^{\text {th }}, 2013$, when occurred the sprouting of the first cultivars and only 37 hours of chill until July $18^{\text {th }}$,
2014, when 'Woodard' started budbreak (Table 2). These values are considered insufficient to attend the demand of the highbush cultivars. This unproductive behavior was also observed in the region of Pelotas$\mathrm{RS}$, with the same cultivars, did not produce with only 368 hours chill (PASA et al., 2014). 'Aliceblue', despite belonging to the rabbiteye group, have not produced either in the first cycle and produced very little in the second. Low production of this cultivar may be related to other climatic and soil factors.

In the 2014/2015 cycle, when the plants had three years old, 'Climax', 'Delite', 'Bluegem' and 'Powderblue' stood out as the most productive. The highlight was the cultivar Climax, which produced $1,057 \mathrm{~g} \mathrm{pl}^{-1}$, superior to $350 \mathrm{~g} \mathrm{pl}^{-1}$ reported by ANTUNES et al. (2008) for the same cultivar in the region of Pelotas-RS. A productivity of 
Table 4 - Climatic characteristics in 2013 and 2014 in Pinhais, PR, Brazil ${ }^{(1)}$.

\begin{tabular}{|c|c|c|c|c|c|c|c|c|c|c|c|c|}
\hline Characteristics & JAN & FEB & MAR & APR & MAY & JUN & JUL & AUG & SEP & OCT & NOV & $\mathrm{DEC}$ \\
\hline \multicolumn{13}{|c|}{ 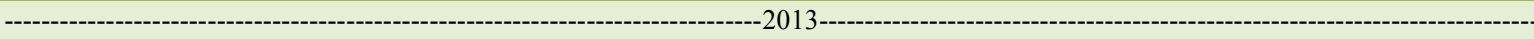 } \\
\hline Maximum temperature $\left({ }^{\circ} \mathrm{C}\right)$ & 25.06 & 26.74 & 24.31 & 23.66 & 21.55 & 19.40 & 18.81 & 20.45 & 21.20 & 22.69 & 23.65 & 26.15 \\
\hline Mean temperature $\left({ }^{\circ} \mathrm{C}\right)$ & 19.14 & 20.43 & 18.77 & 17.06 & 15.45 & 14.24 & 12.45 & 13.60 & 15.20 & 16.64 & 17.95 & 20.12 \\
\hline Minimum temperature $\left({ }^{\circ} \mathrm{C}\right)$ & 15.42 & 16.71 & 15.24 & 12.60 & 10.85 & 10.79 & 7.37 & 8.02 & 10.59 & 12.51 & 14.17 & 16.17 \\
\hline Precipitation (mm) & 58.6 & 277.8 & 128.2 & 49.8 & 88.8 & 160.0 & 125.6 & 28.0 & 173.4 & 99.8 & 105.6 & 101.4 \\
\hline Chilling hours $\left(<7.2^{\circ} \mathrm{C}\right)$ & 0 & 0 & 0 & 0 & 32 & 11 & 110 & 77 & 18 & 0 & 0 & 0 \\
\hline \multicolumn{13}{|c|}{ 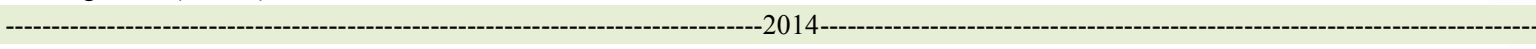 } \\
\hline Maximum temperature $\left({ }^{\circ} \mathrm{C}\right)$ & 28.70 & 28.11 & 25.22 & 22.57 & 20.69 & 20.07 & 19.20 & 22.12 & 22.32 & 25.42 & 24.47 & 26.58 \\
\hline Mean temperature $\left({ }^{\circ} \mathrm{C}\right)$ & 21.79 & 21.35 & 19.58 & 17.58 & 15.16 & 14.95 & 13.25 & 15.02 & 16.12 & 17.49 & 18.52 & 19.97 \\
\hline Mininum temperature $\left({ }^{\circ} \mathrm{C}\right)$ & 17.39 & 17.33 & 16.13 & 14.53 & 11.78 & 11.13 & 9.54 & 9.19 & 12.54 & 13.37 & 14.80 & 16.06 \\
\hline Precipitation $(\mathrm{mm})$ & 198.6 & 135.2 & 121.2 & 68.4 & 88.0 & 164.8 & 34.4 & 69.8 & 178.0 & 72.6 & 124.0 & 220.6 \\
\hline Chilling hours $\left(<7.2^{\circ} \mathrm{C}\right)$ & 0 & 0 & 0 & 0 & 0 & 21 & 37 & 39 & 0 & 0 & 0 & 0 \\
\hline
\end{tabular}

${ }^{(1)}$ Source: SIMEPAR.

4,315kg ha ${ }^{-1}$ in Pinhais-PR may be estimated, far higher than the estimated $900 \mathrm{~kg} \mathrm{ha}^{-1}$ productivity when cultivated using raffia and polypropylene soil coverage in Pelotas-RS (PASA et al., 2014). 'Climax' was the most productive and presented good fruit size $(14.69 \mathrm{~mm})$ and weight $(1.61 \mathrm{~g})$, similar to those observed by PASA et al. (2014), who obtained fruits of 14.13 to $16.54 \mathrm{~mm}$ and weighting from 1.3 to $1.65 \mathrm{~g}$, and better results than reported by ANTUNES et al. (2008), of $14.50 \mathrm{~mm}$, and $1.32 \mathrm{~g}$ for the same cultivar in the region of Pelotas-RS. These results confirmed the possibility of cultivating rabbiteye blueberries in mild winter conditions, such as those occuring in Pinhais-PR, latitude $25^{\circ}$ South. In latitude $25^{\circ}$ North, HUANG \& LI (2015) observed that in such subtropical conditions, i.e. mild winter and no frosts, leaves of the same cultivars remained green and did not fall during winter. These results demonstrated the adaptation plasticity of the rabbiteye group cultivars that, even originary from United States regions with 450 to 600 chilling hours (LOBOS \& HANCOCK, 2015), produce in warmer regions either. It was confirmed in the present study with young plants of rabbiteye, which should increase the production in the next seasons.

Chemical characteristics were different among the cultivars and crop cycles. Variability cycle to cycle was also observed in many experiments with highbush and rabbiteye cultivars in The United States (GÜNDÜZ et al., 2015). In general, the blueberries chemical characteristics evaluated in this study are within the considered ideal range for good quality blueberries, with $\mathrm{pH}$ between 2.25 and 4.25 , total soluble solids higher than $10 \%$, acidity among 0.3 to $1.3 \%$ and ratio between 10 and 33 (BEAUDRY, 1992).

The $\mathrm{pH}$, soluble solids and acidity determinations contributed to the assumption of the fruits acceptability and that there are differences among the cultivars and years (Table 3 ). The $\mathrm{pH}$ and acidity of the fruit are used to show the fruit quality and the stage of ripeness (SANTANA et al., 2004). The $\mathrm{pH}$ values were lower than those reported by SOUSA et al. (2006) in assessing behavior of American blueberry cultivars grown in Portugal.

'Powderblue' stood out among the cultivars with higher soluble solids in the two evaluation cycles, 11.82 and $13.27^{\circ}$ Brix. These values are close to the average of $12.60^{\circ}$ Brix reported in three consecutive harvests, in the region of Pelotas-RS (ANTUNES et al., 2008). Soluble solids are strongly affected by cultivar, more than other factors (PALMA et al., 2016). Also presenting low acidity, 'Powderblue' was superior regarding to ratio, reaching values of 18.50 and 19.56 in the evaluated cycles. This cultivar also presented low acidity $(0.66 \%)$ when grown in Manor-Georgia (USA), but the ratio in this location was higher (23.8) because the obtained soluble solids content was $15.67^{\circ}$ Brix (GÜNDÜZ et al., 2015). In this American State, blueberry cultivation had a break through with the development of cultivars with lower demand in chilling by introduction of genes from local native species in the most demanding cultivars of the northern highbush group. These cultivars were expanded to Chile (1980), Argentina and Spain (1990), California (2000) and more recently to Mexico, Peru and Ecuador (2010) (LOBOS \& HANCOCK, 2015). 
Studies that relate ratio with acceptability of blueberry fruits are rather scarce and according to SAFTNER et al. (2008) the acceptability of fruits is best related to flavor, succulence, sweetness and appearance than with instrumental measurements. However, BEAUDRY (1992) mentions that a blueberry ratio between 10 and 33 indicates that the fruit displays good quality. 'Climax' stood out in the 2013/2014 cycle with high soluble solids content and low acidity, reaching a ratio of 20.57 . However, in the next cycle, because of the high acidity $(1.28 \%)$, it was ranked among the cultivars with smaller ratio (8.89). Acid value was much higher than reported by GÜNDÜZ et al. (2015), who reported $0.27 \%$ for this cultivar in the region of Manor-Georgia (EUA), while the ratio reached was 48.6. The difference between the years may be related to climatic factors, as in the second cycle the cultivars generally showed an increase in acidity and reduction of the ratio. In the second cycle, the harvest took place in November, which was rainier and had lower temperatures than December of the previous year (Table 2).

\section{CONCLUSION}

The flowering period in Pinhais-PR for all cultivars is from August to September, and harvest period from November to December. The most productive cultivars in mild winter conditions are the rabbiteyes Climax, Delite, Bluegem and Powderblue, while the highbush cultivars produce just few fruits. All cultivars have good fruit quality.

\section{ACKNOWLEDGEMENTS}

To Conselho Nacional de Desenvolvimento Científico e Tecnológico (CNPq) and Fundação Araucaria for financial support for development of the project.

\section{REFERENCES}

ANTUNES, L.E.C. et al. Phenology, production and quality of blueberry cultivars. Pesquisa Agropecuária Brasileira, v.43, n.8, p.1011-1015, 2008. Available from: <http://www.scielo.br/scielo.php?script=sci arttext\&pid=S0100-204X2008000800009\&lng=en\&nrm=iso >. Accessed: Aug. 23, 2016. doi: 10.1590/S0100-204X2008000800009.

BEAUDRY, R.M. Blueberry quality characteristics and how can they be optimized. Annual Report of the Michigan State Horticulture Society, v.122, p.140-145, 1992.

CANTUARIAS-AVILÉS, T. et al. Variety introduction of low chilling demand in the state of São Paulo. Revista Brasileira de Fruticultura, v.36, n.1, p.139-147, 2014. Available from: $<$ http://www.scielo.br/scielo.php?script=sci arttext\&pid=S010029452014000100015\&lng=pt\&nrm=iso>. Accessed: Aug. 23, 2016. doi: 10.1590/0100-2945-453/13
CARDEÑOSA, V. et al. Influence of genotype, cultivation system and irrigation regime on antioxidant capacity and selected phenolics of blueberries (Vaccinium corymbosum L.). Food Chemistry, v.202, n.1, p.276-283, 2016. Available from: <http:// www.sciencedirect.com/science/article/pii/S0308814616301212>. Accessed: Aug. 23, 2016. doi: 10.1016/j.foodchem.2016.01.118.

ENGLAND, G.K. An overview of the blueberry industry in Florida. Journal of the American Pomological Society, v.69, n.1, p.2-3, 2015. Available from: <http://www.pubhort.org/aps/69/ v69 n1 a1.htm>. Accessed: Aug. 23, 2016.

GÜNDÜZ, K. et al. Variation among highbush and rabbiteye cultivars of blueberry for fruit quality and phytochemical characteristics. Journal of Food Composition and Analysis, v.38, p.69-79, 2015. Available from: <http://www.sciencedirect. com/science/article/pii/S0889157514001628>. Accessed: Aug. 23, 2016. doi: 10.1016/j.jfca.2014.09.007.

HUANG, S.; LI, K. Dormant season fertigation promotes photosynthesis, growth, and flowering of 'Blueshower' rabbiteye blueberry in warm climates. Horticulturae Environmental Biotechnology, v.56, n.6, p.756-761, 2015. Available from: $<$ http:// link.springer.com/article/10.1007/s13580-015-0105-2>. Accessed: Aug. 23, 2016. doi: 10.1007/s13580-015-0105-2.

KANG, J. et al. Phenolic acids of the two major blueberry species in the US market and their antioxidant and anti-inflammatory activities. Plant Foods for Human Nutrition, v.70, n.1, p.56-62, 2015. Available from: <http://link.springer.com/article/10.1007/s11130-014-0461-6>. Accessed: Aug. 23, 2016. doi: 10.1007/s11130-014-0461-6.

LI, D. et al. Profiling of anthocyanins from blueberries produced in China using HPLC-DAD-MS and exploratory analysis by principal component analysis. Journal of Food Composition and Analysis, v.47, p.1-7, 2016. Available from: <http://www.sciencedirect.com/ science/article/pii/S0889157515001957>. Accessed: Aug. 23, 2016. doi: 10.1016/j.jfca.2015.09.005.

LOBOS, G.A.; HANCOCK, J.F. Breeding blueberries for a changing global environment: a review. Frontiers in Plant Science, v.6, p.782, 2015. Available from: <http://journal. frontiersin.org/article/10.3389/fpls.2015.00782>. Accessed: Aug. 23, 2016. doi: 10.3389/fpls.2015.00782.

MUÑOZ-VEGA, P. et al. Effects of organic fertilizers on the vegetative, nutritional, and productive parameters of blueberries 'Corona', 'Legacy', and 'Liberty'. Chilean Journal of Agricultural Research, v.76, n.2, p.201-212, 2016. Available from: <http:// www.chileanjar.cl/files/V76i2Y2016id4452.pdf>. Accessed: Mar. 18, 2017. doi: 10.4067/S0718-58392016000200010.

PALMA, M.J. et al. Yield components and fruit quality of highbush blueberries (Vaccinium corymbosum L.) in three production areas in the Maule Region, Chile. Acta Horticulturae, v.1117, p.125-131, 2016. Available from: $<$ http://www.actahort.org/books/1117/1117 21.htm $>$. Accessed: Mar. 18, 2017. doi: 10.17660/ActaHortic.2016.1117.21.

PASA, M.S. et al. Performance of rabbiteye and highbush blueberry cult ivars as affected by mulching. Revista Brasileira de Fruticultura, v.36, n.1, p.161-169, 2014. Available from: <http://www.scielo.br/scielo. php?script=sci_arttext\&pid=S0100-29452014000100018\&lng=pt\&nr m=iso $>$. Accessed: Aug. 23, 2016. doi: 10.1590/0100-2945-236/13.

PICOLOTTO, L. et al. Dormancy breaking of and protected cultivation on blueberry yield. Revista Brasileira de Fruticultura, v.36, n.1, 
p.271-278, 2014. Available from: <http://www.scielo.br/scielo. php?script=sci_arttext\&pid=S0100-29452014000100033\&lng=pt\&nr m=iso $>$. Accessed: Aug. 23, 2016. doi: 10.1590/0100-2945-247/13.

RETAMAL-SALGADO, J. et al. Influence of microclimatic conditions under high tunnels on the physiological and productive responses in blueberry 'O'Neal'. Chilean Journal of Agricultural Research, v.75, n.3, p.291-297, 2015. Available from: <http:// www.chileanjar.cl/files/V75i3Y2015id4392.pdf>. Accessed: Mar. 18, 2017. doi: 10.4067/S0718-58392015000400004.

RETAMALES, J.B. et al. Blueberry production in Chile: current status and future developments. Revista Brasileira de Fruticultura, v.36, n.1, p.58-67, 2014. Available from: <http:// www.scielo.br/scielo.php? script $=$ sci_arttext\&pid $=$ S 0100 29452014000100008\&lng=pt\&nrm=iso >. Accessed: Aug. 23, 2016. doi: 10.1590/0100-2945-446/13.
SAFTNER, R. et al. Instrumental and sensory quality characteristics of blueberry fruit from twelve cultivars. Postharvest Biology and Technology, v.49, n.1, p.19-26, 2008. Available from: <http:// www.sciencedirect.com/science/article/pii/S0925521408000173>. Accessed: Aug. 23, 2016. doi: 10.1016/j.postharvbio.2008.01.008.

SANTANA, L.R.R. et al. Improved genotypes of papaya (Carica papaya L.): sensory and physico-chemical evaluation. Ciência e Tecnologia deAlimentos, v.24, n.2, p.217-222, 2004. Available from: $<$ http://www.scielo.br/scielo.php?script=sci_arttext\&pid=S0101$20612004000200010 \& \operatorname{lng}=$ pt\&nrm=iso $>$. Accessed: Aug. 23, 2016. doi: 10.1590/S0101-20612004000200010.

SOUSA, M.B. et al. A survey of quality factors in highbush and rabbiteye blueberry cultivars in Portugal. Acta Horticulturae, n.715, p.567-572, 2006. Available from: <http://www.actahort.org/books/715/715 87. htm>. Accessed: Aug. 23, 2016. doi: 10.17660/ActaHortic.2006.715.87. 